\title{
К ВОПРОСУ КЛАССИФИКАЦИИ МЕР АДМИНИСТРАТИВНОГО ПРИНУЖДЕНИЯ, ПРИМЕНЯЕМЫХ ТАМОЖЕННЫМИ ОРГАНАМИ
}

Аннотация. Предметом проведенного исследования является система мер административного принуждения, применяемых должностными лицами таможенных органов, правовые нормы административного принуждения в срере таможенных правоотношений. В статье описаны различные виды мер административного принуждения и их классификации, предлагаемые разными исследователями, изложены критерии классификаций. Учитывая специфику деятельности таможенных органов, автором предложен свой вариант, по мнению автора, наиболее полной, структурированной, логически выверенной и научно обоснованной классификации мер административного принуждения, применяемых таможенными органами. Методологическую основу исследования составил комплекс общенаучных и частнонаучных методов познания (формально-правовой, аналитический, нормативно-логический, системный и др.). Автор выделяет подход А.В. Сургутсковой к основаниям классификации мер административного принуждения, соглашаясь с ним и с выводом о том, что уяснение сущности административно-правового принуждения при нарушении таможенных правил и отграничение его от других видов государственно-правового принуждения придает практическую ценность классификации мер административного принуждения в срере таможенных правоотношений.

Ключевые слова: административное принуждение, критерии, основания, классификация, таможенные органы, меры, обеспечение производства, пресечение, наказание, ответственность.

Abstract. The research subject is the system of administrative enforcement measures applied by the officials of customs authorities, and the legal provisions of administrative enforcement in the sphere of customs legal relations. The author describes various types of administrative enforcement, and their classifications, proposed by the researchers, and explains the criteria of classification. Taking into account the specificity of customs authorities, the author proposes his own variant of, in his opinion, a more comprehensive, structured, logically verified and scientifically grounded classification of administrative coercive measures applied by customs authorities. The research methodology is based on the set of general scientific and specific methods of cognition (technical, analytical, logical, system, etc.). The author marks out the approach of A.V. Surgutkovskaya to the grounds of classification of administrative coercive measures, agrees with them and with the conclusion that the understanding of the essence of administrative enforcement in the cases of violation of customs rules, and its differentiation from other forms of administrative enforcement attaches practical value to the classification of administrative enforcement measures in the sphere of customs legal relations.

Key words: administrative enforcement, criteria, grounds, classification, customs authorities, measures, procedure, suppression, punishment, liability, administrative enforcement, criteria, justification, classification, customs authorities, measures, ensuring the production, suppression, punishment, responsibility.

$\mathrm{B}$ виду разнообразия мер административного принуждения, которые вправе применять уполномоченные государственные органы, вопрос их классификации имеет большое значение как для теории административного права, так и для правоприменительной практики.

Обратим внимание, что в научной и учебной литературе, как правило, выделяют следующие виды мер административного принуждения:

- меры административного пресечения и обеспечения производства;

- меры административной ответственности;

- административно-предупредительные;

- $\quad$ административно-восстановительные меры.

Меры административного пресечения и обеспечения производства в свою очередь также могут быть сгруппированы в несколько видов:
1) имущественные (изъятие оружия, снос незаконно возведенных зданий и др.);

2) технические (запрещение эксплуатации неисправного транспорта, запрещение ремонтностроительных работ на улицах или дорогах, если не соблюдаются требования по обеспечению общественной безопасности, и др.);

3) финансовые (отзыв лицензии на право осуществления финансовых операций, взимание финансовых средств в доход бюджета и др.);

4) медико-санитарного характера (запрещение эксплуатации предприятий торговли или общественного питания из-за их антисанитарного состояния, отстранение от работы инфекционных больных и др.);

5) связанные с осуществлением лицензионноразрешительной системы (аннулирование 
разрешения, приостановление действия лицензии);

6) специального (исключительного) назначения (применение огнестрельного оружия, химических слезоточивых веществ, резиновых палок, наручников и др.);

7) применяемые непосредственно к личности правонарушителя (непосредственное физическое воздействие, административное задержание и др.).

Заметим, что меры административного пресечения тесно связаны с мерами административной ответственности, зачастую предшествуя им и обеспечивая возможность фактической реализации административной ответственности.

Административная ответственность в свою очередь является видом юридической ответственности за нарушение административного или иного законодательства, выражающаяся в применении уполномоченным органом (должностным лицом) административного наказания к лицу, совершившему правонарушение.

С административной ответственностью тесным образом связано административное взыскание, являющееся ее мерой применяемой в связи с совершением административного правонарушения [1].

Характеризуя административную ответственность, как правило, выделяют следующие ее основные черты:

- административная ответственность устанавливается только федеральными законами или законами субъектов РФ в отличие от мер административного принуждения, которые могут устанавливаться и подзаконными актами (за нарушения таможенных правил - только федеральными законами (далее - КоАП РФ), так как согласно ч.1 ст.1 Конституции РФ таможенное дело относится к исключительному ведению РФ);

- основанием административной ответственности является административное правонарушение;

- субъектами административной ответственности могут быть как физические, так и юридические лица;

- привлечение административного наказания не влечет судимости, что характерно для уголовной ответственности, и увольнения с работы. Лицо, которому назначено административное наказание за совершение административного правонарушения, считается подвергнутым данному наказанию со дня вступления в законную силу постановления о назначении административного наказания до истечения одного года со дня окончания ис- полнения данного постановления (ст. 4.6 КоАП РФ);

- административные наказания применяется широким кругом уполномоченных органов и должностных лиц: судами (судьями), уполномоченными органами исполнительной власти, органами местного самоуправления и их должностными лицами (гл. 23 КоАП РФ);

- административные наказания применяются органами и должностными лицами к неподчиненным им правонарушителям;

- $\quad$ в отличие от уголовных дел, рассматриваемых в соответствии с уголовно-процессуальным законодательством, дисциплинарных, рассматриваемых в соответствии с нормами, устанавливающими порядок дисциплинарного производства, меры административной ответственности применяются согласно законодательству, регламентирующему производство по делам об административных правонарушениях (КоАП РФ).

Очевидно, что административная ответственность обладает рядом особенностей, отличающих ее от других видов ответственности, однако основная особенность административной ответственности состоит в том, что ее основанием является административное правонарушение, а мерами административные наказания.

Основными видами административных наказаний являются: предупреждение; административный штраф; возмездное изъятие орудия совершения или предмета административного правонарушения; конфискация орудия совершения или предмета административного правонарушения; лишение специального права, предоставленного физическому лицу (права управления транспортным средством, права охоты, права на эксплуатацию радиоэлектронных средств или высокочастотных устройств); административный арест; административное выдворение за пределы РФ иностранного гражданина или лица без гражданства; дисквалификация; административное приостановление деятельности.

Меры обеспечения производства по делам об административных правонарушениях выделены законодателем в отдельную 27 главу КоАП РФ и используются в целях пресечения административного правонарушения, установления личности нарушителя, составления протокола об административном правонарушении при невозможности его составления на месте выявления административного правонарушения, обеспечения своевременного и правильного рассмотрения дела об административном правонарушении и исполнения принятого по делу постановления (ч.1 ст. 27.1 КоАП РФ). Их основное назначение - создать необ- 
ходимые условия для реализации норм материального права, устанавливающих ответственность за административные правонарушения.

Наряду с анализом общих классификаций мер административного принуждения, обратим внимание на относительно недавние исследования учёных, предлагавших научные классификации мер административного принуждения при нарушении таможенных правил.

Е.И. Сидоров, учитывая предложенный Д.Н. Бахрахом критерий деления мер административного принуждения (трёхзвенная классификация; основания - способ охраны правопорядка), выделяет:

- меры административного пресечения;

- $\quad$ меры обеспечения производства по делам об административных правонарушениях;

- $\quad$ меры ответственности [2,10].

Ч.В. Тедтоев, также следуя примеру Д.Н. Бахраха, применившего в качестве основания дифференциации способ охраны правопорядка, предлагает четырехзвенную классификацию мер административного принуждения при нарушении таможенных правил:

- $\quad$ меры административной ответственности;

- меры административного процессуального обеспечения;

- $\quad$ меры административного пресечения;

- меры административного восстановления $[3,2]$.

Бакаева О.Ю., Матвиенко Г.В., Калашникова И.А. и ряд других исследователей подразделяют меры административного принуждения при нарушении таможенных правил на пять групп:

- $\quad$ меры административного пресечения;

- меры обеспечения производства по делам об административных правонарушениях в области таможенного дела;

- $\quad$ меры административной ответственности;

- административно-восстановительные меры;

- административно-предупредительные меры [4,290], [5.2].

Отдельного внимания, на наш взгляд заслуживает исследование А.В. Сургутсковой, предложившей научную классификацию правового принуждения при нарушении таможенных правил [6].

Как отмечает А.В. Сургутскова, практическая ценность ее классификации заключается в уяснении сущности административно-правового принуждения при нарушении таможенных правил как единого обобщающего понятия и отграничении его от других видов государственно-правового принуждения.

Придерживаясь практики использования учеными нескольких оснований для классификации, первоначально А.В. Сургутскова использует дихотомическое деление административно-принудительных мер на две группы по критерию использования в производстве по делам об административном правонарушении в области таможенного дела, обращая внимание при этом, что каждое конкретное дело об административном правонарушении, предусмотренном главой 16 КоАП РФ, представляет собой диалектический сплав как минимум трех составляющих: 1) юридического производства; 2) жизненного случая; 3) совокупности документов [7].

В результате операции первоначального деления А.В. Сургутскова получает следующие самостоятельные ярусы мер:

1) административно-правовые меры принуждения, осуществляемые за рамками производства по делам об административных правонарушениях при нарушении таможенных правил;

2) административно-правовые принудительные меры, применяемые в производстве по делам об административных правонарушениях при нарушении таможенных правил.

А.В. Сургутскова замечает, что ни один из полученных таксонов не является концевым, т.е. далее неделимым, в связи с чем, продолжает операцию деления, используя в качестве традиционного основания способ охраны правопорядка, и получает следующую классификацию мер административного принуждения при нарушении таможенных правил:

I. Административно-правовые меры пресечения презюмируемой и непосредственной опасности нарушения таможенных правил:

1) ординарные:

- приостановление выпуска товаров как на основании заявления обладателя исключительных прав (интеллектуальной собственности) на объекты авторского права и смежных прав, так и без такого заявления;

- уничтожение конфискованных экземпляров произведений и фонограмм, материалов и оборудования, используемых для их воспроизведения, и иных орудий совершения административного правонарушения, предусмотренного ч. 1 ст. 7.12 КоАП РФ;

- приостановление действия свидетельства о включении в один из реестров лиц, осуществляющих деятельность в области таможенного дела, при применении отзыва свидетельства о включении в один из реестров лиц, осуществляющих деятельность в области таможенного дела;

- отзыв свидетельств о включении лиц, осуществляющих деятельность в области таможенного дела, в таможенные реестры; 
- приостановление действия квалификационного аттестата специалиста по таможенным операциям; аннулирование квалификационного аттестата специалиста, непосредственно осуществляющего таможенные операции;

2) экстраординарные: применение физической силы; применение специальных средств; использование служебных собак; применение огнестрельного оружия.

II. Административно-правовые принудительные меры, применяемые в производстве по делам об административных правонарушениях при нарушении таможенных правил:

1) административно-процессуальные меры принуждения: доставление;

- задержание; привод; личный досмотр и досмотр вещей, находящихся при физическом лице; досмотр транспортных средств; осмотр принадлежащих юридическому лицу или индивидуальному предпринимателю помещений, территорий и находящихся там вещей и документов; изъятие вещей и документов; взятие проб и образцов; арест товаров, транспортных средств и иных вещей; временный запрет деятельности.

2) меры административного наказания:

- предупреждение; административный штраф; конфискация орудия или предмета совершения административного правонарушения; административный арест; административное приостановление деятельности [6].

Опираясь на работу А.В. Сургутсковой и ее логичный принципиальный подход к классификационному делению мер административного принуждения, применяемых таможенными органами, в качестве обособленной группы мер административно-правового принуждения, содержащихся в таможенном законодательстве, выделим:

- отзывы свидетельств о включении в различные реестры (таможенных перевозчиков, владельцев складов временного хранения, таможенных представителей, владельцев таможенных складов),

- отзыв квалификационных аттестатов специалистов по таможенным операциям;

- принудительное взыскание таможенных платежей.

В итоге, делая ряд поправок классификации, предложенной А.В. Сургутсковой, в связи с изменившимся таможенным законодательством и устраняя некоторые технические неточности данной классификации, и в то же время, соглашаясь с принципиальным подходом названного автора к классификации мер административного принуждения, предлагаем следующий авторский вариант классификация мер административного принуждения, применяемых таможенными органами:

I. Административно-правовые меры пресечения опасности нарушения законодательства и недопущения (устранения) вредных последствий:

1) общие:

- приостановление выпуска товаров как на основании заявления обладателя исключительных прав (интеллектуальной собственности) на объекты авторского права и смежных прав, так и без такого заявления;

- уничтожение конфискованных экземпляров произведений и фонограмм, материалов и оборудования, используемых для их воспроизведения, и иных орудий совершения административного правонарушения, предусмотренного ч. 1 ст. 7.12 КоАП РФ;

- исключение из реестров лиц, осуществляющих деятельность в области таможенного дела (таможенных перевозчиков, владельцев складов временного хранения, таможенных представителей, владельцев таможенных складов, владельцев магазинов беспошлинной торговли);

- приостановление действия и отзыв свидетельства о включении в реестр уполномоченных экономических операторов и исключение из реестра уполномоченных экономических операторов;

- отзыв квалификационного аттестата специалиста по таможенным операциям;

- принудительное взыскание таможенных платежей (мера устранения вредных последствий неправомерного поведения субъектов таможенных правоотношений).

2) специальные:

- применение физической силы;

- применение специальных средств;

- использование служебных собак;

- применение огнестрельного оружия.

II. Административно-правовые принудительные меры, применяемые при производстве по делам об административных правонарушениях таможенными органами:

1) административно-процессуальные меры принуждения (меры обеспечения производства по делам об административных правонарушениях):

- доставление;

- административное задержание;

- привод;

- личный досмотр и досмотр вещей, находящихся при физическом лице;

- досмотр транспортных средств;

- осмотр принадлежащих юридическому лицу или индивидуальному предпринимателю по- 


\section{Административное и муниципальное право 3 (99) • 2016}

мещений, территорий и находящихся там вещей и документов;

- изъятие вещей и документов;

- взятие проб и образцов;

- $\quad$ арест товаров, транспортных средств и иных вещей;

- временный запрет деятельности, задержание судна, доставленного в порт РФ, арест судна, доставленного в порт РФ, залог за арестованное судно.

2) меры административного наказания:

- предупреждение; административный штраф; конфискация орудия или предмета соверше- ния административного правонарушения (могут применяться по делам о нарушении таможенных правил (16 глава КоАП РФ));

- административный арест;

- обязательные работы.

Данная классификация мер административного принуждения, применяемых таможенными органами, на наш взгляд, является наиболее полной, структурированной, логически выверенной и научно обоснованной среди различных вариантов предлагаемых исследователями классификаций.

\section{Библиография:}

1. Основы права. Под редакцией профессора 3. Г. Крыловой. ГУП Издательство «Высшая школа»2000 / http://www. bibliotekar.ru/osnovy-prava-2/32.htm.

2. Сидоров Е.И. Меры обеспечения производства по делам об административных правонарушениях в области таможенного дела: Автореф. дисс.... канд. юрид. наук. М., 2008.

3. Тедтоев Ч.В. Меры административного принуждения, применяемые таможенными органами: Дисс.... канд. юрид. наук. М., 2001.

4. Бакаева О.Ю., Матвиенко Г.В. Таможенное право России: Учебник / Отв. Ред. Н.И. Химичева. 2-е изд., перераб. и доп. М., 2007. С.290-302/

5. Калашникова И.А. Административное производство по применению мер принуждения таможенными органами Российской Федерации: Дисс.... канд. юрид. наук. М., 2008. С.2.

6. Сургутскова А.В. Административно-правовое принуждение, применяемое при нарушении таможенных правил. Автореф.... дисс....канд. юрид. наук. Юж.-Ур. гос. ун-т.-Омск, 2011.-201 с.

7. Кальницкий В.В., Марфицин П.Г. К вопросу о понятии «уголовное дело» // Научный вестник Омской академии МВД России. 2001. N 1(13). С. 32.

\section{References (transliterated):}

1. Osnovy prava. Pod redaktsiei professora 3. G. Krylovoi. GUP Izdatel'stvo «Vysshaya shkola»2000 / http://www.bibliotekar. ru/osnovy-prava-2/32.htm.

2. Sidorov E.I. Mery obespecheniya proizvodstva po delam ob administrativnykh pravonarusheniyakh $\mathrm{v}$ oblasti tamozhennogo dela: Avtoref. diss.... kand. yurid. nauk. M., 2008.

3. Tedtoev Ch.V. Mery administrativnogo prinuzhdeniya, primenyaemye tamozhennymi organami: Diss.... kand. yurid. nauk. M., 2001.

4. Bakaeva O.Yu., Matvienko G.V. Tamozhennoe pravo Rossii: Uchebnik / Otv. Red. N.I. Khimicheva. 2-e izd., pererab. i dop. M., 2007. S.290-302/

5. Kalashnikova I.A. Administrativnoe proizvodstvo po primeneniyu mer prinuzhdeniya tamozhennymi organami Rossiiskoi Federatsii: Diss.... kand. yurid. nauk. M., 2008. S.2.

6. Surgutskova A.V. Administrativno-pravovoe prinuzhdenie, primenyaemoe pri narushenii tamozhennykh pravil. Avtoref.... diss....kand. yurid. nauk. Yuzh.-Ur. gos. un-t.-Omsk, 2011.-201 s.

7. Kal'nitskii V.V., Marfitsin P.G. K voprosu o ponyatii «ugolovnoe delo» // Nauchnyi vestnik Omskoi akademii MVD Rossii. 2001. N 1(13). S. 32. 